\title{
Jasmina Talam
}

Akademija za glasbo, Univerza v Sarajevu

Academy of Music, University of Sarajevo

\section{Creation, Transmission and Performance: Guslars in Bosnia and Herzegovina}

\section{Ustvarjanje, prenos in izvajanje: guslarji v Bosni in Herzegovini}

Prejeto: 20. januar 2015

Sprejeto: 31. marec 2015

Ključne besede: tradicija, guslarji, Bosna in Hercegovina

\section{IZVLEČEK}

Petje ob spremljavi gusel je zelo pomembna oblika vokalno-inštrumentalnega nastopanja v glasbeni tradiciji Bosne in Hercegovine. Dotični prispevek želi predstaviti zgodovinske vire in raziskave o petju s spremljavo gusel in načine, po katerih so pesmi ustvarjene, prenesene in kako guslarji z njimi nastopajo.
Received: 20th January 2015

Accepted: 31st March 2015

Keywords: tradition, guslars, Bosnia and Herzegovina

\section{ABSTRACT}

Singing to accompaniment of the gusle is a very important form of vocal-instrumental performance in the musical tradition of Bosnia and Herzegovina. This paper will present historic sources and research on singing to gusle accompaniment, and the methods by which songs are created, transmitted and performed by guslars.

\section{Historical sources and research into singing to the gusle in Bosnia and Herzegovina}

Research into the gusle and the practice of singing to gusle accompaniment in Bosnia and Herzegovina draws on a number of sources, ranging from historical documents and museum collections to ethnomusicological descriptions and audio, photo and video recordings. The tradition of singing to the gusle has been a subject of interest for various local and foreign ethnomusicologists, linguists and travel 
writers since the sixteenth century. This paper will present some of the most important sources for research of tradition of vocal performance to gusle accompaniment in Bosnia and Herzegovina.

The first mention of the gusle in Bosnia and Herzegovina in a historical source is found in the Putopis, kroz Bosnu, Srbiju, Bugarsku i Rumeliju - 1530 [Travels in Bosnia, Serbia, Bulgaria and Rumelia - 1530] (2001) written by the Slovenian traveller Benedikt Kuripešić. His description of the singing of Bosniacs (Muslim Slavs) and Croats in the service of Duke Radoslav Pavlović provides important information about music in the mediaeval Bosnian state. (see Kuripešić 2001)

Luka Marjanović collected an enormous amount of epic songs from singers in north-western Bosnia during a decade of fieldwork in the 1880s. He transcribed in manuscript from singers and published the songbooks Hrvatske narodne pjesme, što se pjevaju u gornjoj hrvatskoj Krajini i u turskoj Hrvatskoj [Croatian folk songs, sung in the Upper Krajina and Turkish Croatia, 1864] and Hrvatske narodne pjesme [Croatian folk songs, III-IV, 1898-99]. The Croatian musicologist Franjo Kuhač notes that "you can find a small gusle in every house in Bosnia and Herzegovina; young and old, men and women, even children play the gusle (guslaju); priest and soldier, farmer and mayor, outlaw and beggar. The people greatly appreciate artistry in gusle playing, handing a gusle to a guest straight away (even if he is a stranger), as soon as he has been greeted and refreshments provided, saying he should sing to its accompaniment. The gusle is a faithful companion, and every joy and every sorrow is told to its accompaniment. Without its sound no festive occasion or celebration can take place; without this consoler the Slavic people could neither withstand their misery nor preserve their nation, or keep their poetry or history within their memories." (Kuhač 1877:7-8)

In his very interesting article "O bosanskoj muzici" ["On Bosnian music"] (1889), Karl Saks states that "Music in Bosnia is closely connected to poetry or, more precisely stated, is in the service of poetry... Bosnians never recite songs, but they tell (sing) them with musical accompaniment or without. Women and girls, young men and children, even the youngest, sing without vocal instrumental accompaniment. Singing to the gusle is reserved specifically for men, especially Christians and Muslims. Singing to the gusle is sometimes lyrical, and sometimes epic" (1889:51-52).

The German traveller Heinrich Renner left a comprehensive record of his travels in Bosnia and Herzegovina at the end of the nineteenth century. He stated that "epic songs, which are recited in a singing voice and with specific rhythm, [...] describe everyday life and heroism." (1900:57)

The Croatian/Austrian ethnographer Friedrich Salomo Krauss made a significant collection (1859-1938) and published a number of collections of folk poetry, particularly from Herzegovina. He also wrote several ethnographic studies and studies of oral poetry.

The first known audio recordings of the Herzegovinian gusle were made for the Berlin Phonogramm-Archiv by the Lithuanian linguist and ethnologist Eduard Wolter (1856-1941) (they are today held by the Berlin Ethnological museum). Rizvan 
Kadrović ${ }^{1}$, a guslar (performer on the gusle) from Trebinje, is recorded on the tape singing to his own accompaniment.

The pioneer of systematic fieldwork research on the traditional oral epic in Bosnia and Herzegovina was Matija Murko. Murko's interest in the epic tradition in Bosnia and Herzegovina was sparked by the publication of collections of epic poetry made by Kosta Hörmann, and later Luka Marjanović. He was primarily interested in epic, but also in epic-lyric songs. Singing was mostly to instrumental accompaniment, generally with gusle. He conducted his first researches in Bosnia and Herzegovina in 1909 on the territory of Bosnian Krajina, but did not make any audio recordings at that time. Murko made his first audio recordings in Bosnia and Herzegovina in north-western Bosnia in 1912. He made 46 recordings, 13 of which have been lost. During 1913 he conducted researches in Sarajevo, Mostar, Široki Brijeg and Nevesinje, recording 36 reels of tape, and published the results of researches conducted in 1912 and 1913 as an associate of the Vienna Phonogrammearchiv ${ }^{2}$. Sixty-nine of a total of 82 audio recordings have been preserved, including 25 epic poems accompanied by gusle ${ }^{3}$. Seventeen years later, in 1930, Murko conducted new research in eastern Bosnia and Sarajevo, and in 1930 from Višegrad, Goražde and Foča down to Sarajevo, and in Humac and Čapljina. He published the results in his classic two-volume study Tragom srpsko-hrvatske narodne epike [On the Track of the Serbo-Croatian Folk Epic] (1951). "The greatness of Murko's work does not lie in the depth of his studies (during his fieldwork he never stayed in one place for any length of time) but in his historiographically and ethnographically rich descriptions of the epic life of the South Slavs in the first decades of the twentieth century" (Dukić 1995: 56-57). Murko's methodology was straightforward: for each recording he completed a form which included information about the singer or instrumentalist (name, age, ethnicity, etc.), data about the recording session (date, time, location of recording, genre and related information) and the text of the song (dictated and sung).

Inspired by Murko's researches, Milman Parry, a distinguished Harvard professor and a pioneer in the study of the oral epic, organised two expeditions to Bosnia and Herzegovina, in the summer of 1933 and between July 1934 and September $1935^{4}$. His researches covered eastern Herzegovina (Nevesinje, Stolac and Gacko) and northwestern Bosnia (Bihać). The Milman Parry Collection consists of 3,500 double-sided aluminium discs on which were recorded verse epics sung to gusle accompaniment,

1 A recording of Rizvan Kadrović is included on the multimedia CD World Map of Music (2006). The recording lasts for 86 seconds and is clearly comprehensible. The photograph is by Walter Wünsch.

2 Murko planned a fourth expedition to Bosnia in the summer of 1914, but was prevented from doing so by the First World War.

3 According to Dr August Loehr, some of Murko's recordings were destroyed during street fighting in Vienna before the end of the Second World War (Murko 1964: 113).

4 In an unpublished manuscript, Milman Parry wrote: „A week previously, while I was defending my doctoral thesis at the Sorbonne, Professor Matija Murko from the University of Prague happened to give a series of lectures in Paris which were later published as La poésie populaire épique en Yougoslavie au début du XXe siècle (The Poetic Folk Epic in Yugoslavia at the Beginning of the Twentieth Century). I saw a notice for these lectures, but observed no interest in them for me. Professor Murko, however, was present at my defence, no doubt at Meille's recommendation, and at that time M. Meillet, as a member of my board, indicated this omission in my two books with his customary ease and simplicity. It was Professor Murko's work, more than anything else, that led me to study oral poetry in general, and then the heroic songs of the Southern Slavs." (Kunić 2013: 24) 
ballads, and interviews with the performers. ${ }^{5}$ In the summer of 1950, Parry's assistant Albert Bates Lord continued his research in eastern Herzegovina (Stolac and Gacko).

In an article entitled "Naša pučka glazbala" ("Our folk instruments") Branko Marić provides a very interesting reflection on the gusle: "An instrument entirely grown from the people, the keeper of our domestic heart. Its appearance reflects the characteristics of moderated seriousness, as if it has been entrusted with the secret of our people's soul. Its origins date from deep in the past. The instrument of our homeland." (Marić 1932:141)

In "Sarajevska čalgija”, Vejsil Ćurčić described the gusle as our "oldest instrument, without which the singing of our epic songs is quite unimaginable, and an instrument which is a part of the furnishings of our farmhouses. It could not be naturalised among the people of Sarajevo, particularly the Agas and Beys; they considered the gusle to be an instrument of country dwellers and people from provincial towns (kasablije). If the gusle nevertheless happened to be heard somewhere in the houses of Agas and Beys in Sarajevo, it was immediately obvious that there was no city dweller (̌̌eherlija) living in that house, and that an immigrant from a country town or the village had came to Sarajevo, and in his hands the gusle was being bowed. Occasionally the gusle might be heard somewhere from an inn (kafana or mejhana). People from Sarajevo did not know how to play the gusle themselves, but gusle players from the provinces, especially Herzegovina, Gacko and Foča, used to pass by. Hasan Falan from Gacko was well known, as was Mehmed Spahić, known as Krivovrat (Crookneck), from Jarčedoli near Sarajevo. There were few gusle players who were professionals, and then only during the period of Ramadan." (Ćurčić 1935:4)

During September and October of 1937, the Südost-Ausschluss der Deutschen Akademie München (South-Eastern Committee of the German Academy in Munich) organized a scientific expedition, the "Bosnienfahrt", with the aim of researching folk music and phonetics. The leader of the project was Gerhard Gesemann, a professor at the German University in Prague, while its members were Kurt Huber and Walter Wünsch. During their stay in Blažuj, near Sarajevo, they recorded several songs with gusle accompaniment.

During his 40-year research career the first Bosnian ethnomusicologist, Cvjetko Rihtman, recorded a considerable number of songs performed with gusle. Rihtman's legacy, which consists of 444 reels of tape 6 and three catalogues, contains detailed information on the gusle players, including the following information in addition to basic biographical data: whether there was a family tradition of gusle performance ${ }^{7}$ how and when the performer had learned the songs; whether he composed songs himself; and explanations of methods and playing techniques by the performer. He left several important works that described gusle players and their repertoire as well as the function and importance of the gusle in Bosnian society.

5 The Milman Parry collection of recordings and transcriptions of Bosnian epic songs is now in the Widener Library of Harvard University.

6 The Academy of Music was shelled frequently during the war (1992-1995), and the Rihtman Collection was relocated to the cellars. A number of magnetic tapes were seriously damaged as a result of the poor conditions.

7 If there was a family tradition of performance on the gusle, data on other family members who were guslars were recorded. 
Other Bosnian ethnomusicologists have followed Rihtman's ethnomusicological research methodology.

The 1992-1995 war and its events altered the demographic picture in Bosnia and Herzergovina. The Department of Musicology and Ethnomusicology of the Sarajevo Academy of Music resumed fieldwork in 2000, and since that time recordings have been made of guslars from Rama, Goražde, Bjelašnica, Trebinje and Pale.

\section{The gusle and singing to the accompaniment of the gusle}

The term gusle comes from the Old Slavonic word gosl - string, and the identical or a similar term is used by other Slavic peoples. The gusle (fiddle) is thought to be the oldest and most widespread chordophone instrument in the rural musical tradition of Bosnia and Herzegovina. Two types of gusle exist in Bosnia and Herzegovina: the Bosnian and Herzegovinan. The Bosnian type has a wider and deeper resonant body, while the Herzegovinan has a shallower resonant body with a rounded or flat roughhewn base. Alija Mušić, a guslar from Drežnica, Mostar, described his gusle in the following terms:

Gusle moje od javorovine / My gusle made of maple wood, a gudalo od šimširovine / With a bow of boxwood, po vama je koža jaretina, / Covered over with kid skin, a po koži kenjac od drveta, /And a wooden bridge on the leather, i po kenjcu strunja od żdrijebeta. / Over the bridge a string of horsehair. Preko strunje skučeno gudalo, / Across the string a tensioned bow, po gudalu moja desna ruka, / Upon the bow my right hand, desna ruka - zelena jabuka. / Right hand - green apple.

The technique of playing the gusle is very simple. The guslar plays the instrument in a seated position, resting the instrument on his left leg above the knee. The bow is held by the right hand, and the string is stopped using the left hand. Ethnomusicological research indicates that the technique of playing the gusle is changing over time, and differences between older and younger guslars have been noted. The older technique of playing the gusle involves stopping the string with the extended first and second finger of the left hand. The third finger is used only to produce a brief appoggiatura. A more recent performance technique involves stopping the string with the pads of the first, second and third fingers, while the fourth finger is only used for the highest pitch. Players begin to play by drawing the bow across the string from right to left. A single movement of the bow is used to produce a melodic phrase slurring several pitches. By using the heel of the bow the player achieves more intense and expressive tones, while tones of lesser intensity are produced by using the tip. (see Talam 2013:84)

From a musical aspect, the formulation of the song requires particular skills from the guslar. The poems sung to gusle accompaniment take the form of a deseterac (tensyllable line) which responds to the language and resources of folk expression (see 
Rihtman 1971:99). The melodies of gusle songs belong to the category of kratki napje$v i$ (short melodies), which permit a fluent, clear and expressive performance of songs with a large number of lines. Notated examples indicate that the metre of the line and the rhythm of the melody are closely interlinked. The gusle "supports the singer with regard to intonation, but the instrument's capabilities, and particularly its actual sonority as determined by the performer's technique and the sonorous ideal designated by musical culture, frequently limit the vocal component" (Lajić Mihajlović 2014:37). Performers compensated for the limited melodic capabilities of the gusle by frequent changes of tempo, various rhythmic motifs, and by interweaving the voice and the instrument. Research to date has demonstrated that the relationship between the vocal and instrumental components "reflects the polyphonic forms encountered in sung practice in certain areas, with their typical treatment of the interval of a second as a consonance, and the voice dipping below the instrumental part". (Rihtman 1971:105)

In addition to their professional skill as instrumentalists and singers, guslars were also required to demonstrate their ability to communicate with the public during their performances. Their success, therefore, did not simply reflect their performance, but also their planning of content that would hold the attention of their audience throughout. Research to date suggests that singers never performed a song in its entirety without any breaks. A performance commences with an instrumental preamble, followed by singing. This instrumental introduction is an important part of the performance, and its duration depends on the performer's skill and abilities. Almost without exception, the better players performed a more extended introduction to display their qualities as performers. The introduction was also important psychological preparation for the guslar, as it allowed him to concentrate on the interpretation or performance of the song's content.

The sung portion frequently began with a prologue whose subject was unconnected with the remainder of the song. The prologue might be "ceremonial, serious, comic, even lascivious, depending on the occasion and who was in the audience". (Rihtman 1971:99)

Tanke gusle ne ostale puste, / The slender gusle did not lie abandoned, ne zapale u dušmanjske ruke, / Nor in the foe's hands did it awaken, već dvorile svoga gospodarca, / But it lay and waited for its master koga no ste i dosad dvorile, / For whom three long years it awaited, brez promine za trije godine. / Waited for those three long years unchanging. Braćo moja i družino moja, O my brothers, and O my companions, a što bi van dalje besjedio? / Of what things shall I speak out now to you? Da pjevamo pjesme od junaka, / Let us sing then songs of mighty heroes, od staroga vakta $i$ zemana, Days of yore, and of those bygone ages, što je bilo u vrijeme davno, / Ancient times, and of the feats performed then, davno bilo, sad se spominilo.. What is past shall now again be spoken.

8 Sung to his own gusle accompaniment by Ilija Brkić, an innkeeper from Posušje (Western Herzegovina). Recorded: Matija Murko. Date: September 14, 1913. Place: Široki Brijeg. Ph 2156. 
The prologue is followed by a brief instrumental interlude, which is followed by the song itself. Extended sung sections and brief instrumental interludes succeed one another throughout the song. The instrument's part is continuous, but it may be observed that its function is dependent on the vocal part. During the brief instrumental interludes the guslar displays his abilities as an instrumentalist through greater melodic and rhythmic freedom, and when he sings and plays simultaneously, the instrumental part functions as accompaniment. Singers do not divide the song into strophes, but into sections whose content depends on the singer's comprehension, stamina and mood (see Murko 1951:394). The sections are not defined so much by poetically coherent content as by the number of melodic phrases that the singer can produce in a single breath. Singers frequently break off their singing at the most exciting part of the song in order to create narrative tension, and guslars hold the attention of their audience by creating dramatic tension through their manner of framing the epic poems. The musical and stylistic qualities of the vocal and instrumental performance have a particular significance in the performance of dramatic works. Melodies are generally unstable, or so variable that it is not possible to locate a fundamental form, but even in notably different variants of a melody it is possible to observe certain regularities with regard to to specific initial and cadential phrases, as well as contrasting forms which arise spontaneously during vocal performance. It may be concluded that the role of the gusle is "very deeply linked with the structure, meaning and performance of epic poetry”. (Čubelić 1971:193)

\section{On singers and guslars}

Ethnomusicological research in Bosnia and Herzegovina has not yet taken proper account of folk instrumentalists, their activities and their role in the social community, but it may be concluded on the basis of the literature that the gusle has been very popular. Statements by informants and documentary materials indicate that male children learned how to play from an early age (see Marić 1932, Rihtman 1982, Foley 2004, Talam 2013), and I have found recordings in museum collections of a number of young children playing the gusle?. The gusle was the property of every class of society - villagers, landholders, teachers, poets, and so forth. Talented individuals who were known for their good knowledge of the folk tradition and their ability to create and improvise on existing texts and melodies were particularly valued.

Previous research has indicated that a large number of guslars were active in Bosnia and Herzegovina. Thanks to foreign researchers, notably Matija Murko and Milman Parry, significant data has been recorded regarding singers to gusle accompaniment and the methods by which guslars' songs were created, transmitted and performed. Murko admired the abilities and skill of guslars/singers, and wondered how it was possible to sing long epics with great rapidity, without mistakes and with impeccable poetic creativity. During his research he took down a poem from dictation and then

9 The Zemaljski muzej (National Museum) in Sarajevo and the Österreichische Museum für Volkskunde (Austrian Museum of Folk Life and Folk Art) hold valuable collections of children's gusle from Bosnia and Herzergovina. 
recorded it being sung. In the majority of cases the dictated poem had fewer lines than the sung version. He concluded that the singers did not learn the material by heart but re-created it each time thanks to their knowledge of the language and of folk verse; in other words they were outstanding improvisers (see Murko 1974:169).

Milman Parry and Albert Lord's research demonstrated that the path to becoming a successful singer capable of satisfying the aesthetic criteria of the audience is a highly demanding one. It consists of three stages. The first is one of listening; children, pupils of between 10 and 15 years old were frequently in a position to listen to singing to gusle accompaniment. Children of this age used to make small instruments whose physical dimensions corresponded to their own size. This was followed by their first attempts at singing and playing the gusle, in other words an attempt to imitate what they had previously heard. This process was described by Šećo Kolić, one of Milman Parry's informants.

"When I was a shepherd boy, they used to come for an evening to my house, or sometimes we would go to someone else's for the evening, somewhere in the village. Then a singer would pick up the gusle, and I would listen to the song. The next day when I was with the flock, I would put the song together, word for word, without the gusle, but I would sing it from memory, word for word, just as the singer had sung it... Then I learned gradually to finger the instrument, and to fit the fingering to the words, and my fingers obeyed better and better... I didn't sing among the men until I had perfected the song, but only among the young fellows in my circle not in front of my elders and betters." (Lord 2000:21)

In the second stage, the young singers/players attempted to perform an entire song in a manner that followed traditional performance practice, in other words the aesthetic standards of the local community. This meant learning how to apply the primary elements of the epic form - the verse metre and the melodic rhythm. Researchers were faced with the question of how the singer could satisfy the demands of rapidly composing a poem without writing it down or learning it by heart. "His tradition comes to the rescue. Other singers have met the same need, and over many generations there have been developed many phrases which express in the several rhythmic patterns the ideas most common in the poetry... [T] he young singer must learn enough of these formulas to sing a song. He learns them by repeated use of them in singing, by repeatedly facing the need to express the idea in song [...] until the resulting formula which he has heard from others becomes a part of his poetic thought" (Ibid.:22). The mastery of formulas handed down by tradition is the fundamental precondition which will later help the singer express his thoughts in the form of the poetic epic, formulate a song in his own style and even begin to compose new songs.

The third stage is the creation of an individual repertoire. In other words, the singer learns previously known songs and adapts them to his own personal style. His repertoire must consist of a number of songs, six or seven at least. The formation of an individual repertoire and the skill to perform the songs in accordance with the unwritten rules of the tradition means the singer is capable of communication with his audience. 
At the point when a singer begins to transmit the epic song tradition through theory and practice, he becomes an artist who creates a tradition, and not merely its carrier. Performance of a song to the accompaniment of the gusle primarily depends on the performer, his knowledge and understanding of the form of the sung epic and his ability as a singer. According to Tvrtko Čubelić, we may divide the singers of the epic into three categories:

- specialist reciters who express their art through the spoken word, while the sung elements are merely incidental;

- the specialist singer who grounds his art in the sung rendition of a specific text;

- performers of epic songs who skilfully combine recited and sung sections (Čubelić 1971:170).

Singers with an outstanding knowledge of language belong to the first category. They have an exceptional feeling for the force and power of words, and are highly skilled in unveiling the concealed rhythmic and expressive qualities of language. They frequently enrich the songs with additional information and descriptions of the characters. To the second category belong singers who are aware of their own vocal abilities and are notable for their skill in singing. Čubelić believes that Filip Višnjić, the earliest known Bosnian guslar, was a singer of this type ${ }^{10}$. To the third and most numerous category belong the singers who skilfully employ elements of recitation (heightened speech) and song, in accordance with their vocal capabilities and knowledge (Ibid.:171).

Only the best could successfully negotiate the path to becoming a successful singer and guslar, and these were few. Good guslars were highly valued and invited to all community celebrations, as well as those organised within the domestic circle of certain families. On these occasions they enjoyed creative freedom and freedom from inhibition. Each new performance presented a reworking of familiar material, so that the songs were continually being reinvented. Singing to gusle accompaniment may therefore be regarded as a productive, and not merely a reproductive, art form. The oral transmission of a story through sung performance involved a considerable number of performers who belonged to various time periods and social classes. A guslar's creation of his own repertoire, as one of the stages on the path to becoming a successful singer, meant learning already extant songs and the ability to "adapt them in line with his own views and tastes" (Murko 1951:509), as well as the composition of new songs based on formulas handed down by tradition. Bosnian folk terminology clearly distinguishes words which indicate the learning of previously existing songs, such as "acquiring" (usvajanje) and "receiving" (primanje). Singers do not learn poems by heart but recreate them, in other words frame them according to their abilities and knowledge. According to Lord, a singer "is not a mere carrier of the tradition but a creative artist making the tradition". (2000:12) The composition and transmission of a song, then, are manifested as various typologies of the same process. Previous research indicates that improvisation is a procedure through which a singer perfects

10 Filip Višnjić (1767-1834) was born in the village Gornja Trnova (Ugljevik). As a child he became blind as a result of smallpox (Variola major). He was a professional gusle player and it is believed that he had travelled throughout the Pashaluk of Bosnia. He was an informant of Vuk Stefanović Karadžić, the distinguished Serbian linguist and collector of folklore. 
his performance and "improves his art". In vernacular speech, improvisation or the arranging of already existing songs is referred to "polishing" (dotjerivati) or "making up" (isknaditi). The singer displays his originality in the method of expression, through his ability to formulate the song in his own individual manner; in other words demonstrating that he has sufficient knowledge and experience to expand it or reduce it in length. In his collection Pjesan naših Muhamedovaca (The Lays of our Mohammedans, 1886) Krauss provided an interesting commentary on his informant Ahmed Šemić from Rotimlje, Stolac, and his version of the poem "The Wedding of Hadji Smailaga's Son" (Ženidba hadži Smailagina sina).

"This is the Lay of Meho Smailagić. It was sung to me in Rotimije (sic) by Ahmed Isakov Šemić, in the uplands three hours' journey south from the confluence of the Buna and Neretva rivers. Ahmed was then 85 years of age. He had learned this lay sixty years before, from Salija Tućaković Kamišević of Hrasno village, four hours from Rotimije and ten from Mostar. There are better singers than Ahmed, and also finer poems among those taken down from him. But this is his longest and it is truly very fine. At this time it is the longest and finest of all the guslars' songs from our Slav peoples in the Balkans to have seen print. There is no maundering (excessive repetition); everything is effective, terse, pertinent. I could not excise five words (verses) from this lay without undoing it." (Krauss 1886:165).

An interesting approach to the study of the transmission of guslars' songs may be observed in the case of Milman Parry. During his fieldwork Parry recorded the same songs, performed by the same singers in 1933 and in 1934, and noted the changes in the content of the song which had taken place over a period of time ${ }^{11}$. One example is the song "Prince Marko and Nina of Koštun" (Marko Kraljević i Nina od Koštuna) as performed by Petar Vidić, a guslar from Stolac (Herzegovina). The first 1933 recording had 154 lines, but in the 1934 performance it had 279. According to Lord, an average performer like Petar Vidić "must carry the brunt of the transmission of the art" (Lord 2000:113). Certain deviations in the content of the song may be observed in his performances, but the thematic structure is preserved.

Although guslars were unable to make a living from singing and playing alone, they were professionals nonetheless. During Ottoman times, and later under AustroHungarian rule they were invited to play in the homes of the wealthy, and their status might be compared to the status of bards in the feudal courts of Mediaeval Bosnia, or of the bards described by Homer. During his fieldwork in 1930, Murko observed "extremely interesting traces of Bosnian feudalism in epic poetry: wealthy Beys and Agas had their permanent bards or ones they supported for entire months, and rewarded them richly". (Murko 1951:362) He concluded that these were particularly talented guslars/singers and outstanding carriers of the folk tradition, and he dedicated special attention to them. One such singer was Ibrahim Vrabac (Knežina, Eastern Bosnia, 1852). As a youth he had served Šahinpašić Bey, who had his own

11 Murko also noticed changes of this kind during his fieldwork in 1909. In fact, Murko had taken down poems from the informants who had been informants of Luka Marjanović 20 years before (Murko 1964:113). 
singers. During his travels with the Bey he had had the opportunity to listen to the singing of other singers. He learned from others, and at the age of 19 he himself became a "Bey's bard"12.

Cvjetko Rihtman states that "the gusle and guslars enjoyed general esteem, and still do today... Because singing to the accompaniment of the gusle is an honour that in the home belongs to the head of the household, and at larger gatherings to the best performers. A festivity without a gusle is unimaginable (especially amongst herdsmen). Even children learning to sing to the gusle are regarded with pride. The honour in singing to the gusle undoubtedly stems from the function of the heroic song in teaching and inspiring the young to imitate the idealised figures it celebrates". (Rihtman 1982:262-263) Telling a story through song provided entertainment through the long winter nights. In the ambience of home or an inn people would listen to guslars, and discuss the songs, their origin and content. In Muslim villages it was the custom during Ramadan to spend the entire night from iftar to sehur to the sound of the gusle ${ }^{13}$. By performing repertoire already familiar or using new melodies, the performer would communicate directly with his listeners. The listeners, on the other hand, appreciated the organisational and musical abilities of the player.

The end of last century saw significant social changes which affected the way of life, and particularly the interest of young people in learning and performing songs to gusle accompaniment in the manner described above. Recent researches indicate that there is a large number of guslars active in Bosnia and Herzegovina, of various ages, levels of education and interests, who may be divided into two categories. The first category predominantly consists of older guslars, whose interpretations are founded on knowledge acquired through oral transmission and many years of experience. They are highly regarded in their local communities owing to their expert interpretations and the repertoire they perform. The second category consists of guslars who have learnt their songs from songbooks, through the media or from commercial recordings. Their interest in guslar songs is often motivated by commercial, and sometimes nationalist, considerations ${ }^{14}$. In many cases the majority of their repertoire consists of songs which they have composed themselves, inspired by event and figures from the recent history of Bosnia and Herzegovina and its neighbours. They appear at various public events, concerts and gusle competitions. They work hard at establishing a rapport with their audience and publicise their appearances. Unlike the guslars who perform in traditional contexts, their positioning on stage "suggests a static bearing and inhibited reactions", and leads to the guslar becoming distanced from his audience

12 Murko was particularly heartened by Ibrahim Vrabac's moral position. Murko offered him money as he had had to travel to the recording location and had to pay for a night's lodging. Vrabac replied "Are you a scholar or a merchant? If you are a scholar I shall take nothing from you, for that would be haram (a sin). If you spread knowledge through the world, it is our duty to help you however much we can (Murko 1951:114).

13 Ramadan is the ninth month of the Muslim calendar, and a month of fasting, abstention from food and drink, crude speech and behaviour, and other things forbidden by Islam. The fast lasts from the pre-dawn meal of sehur until sunset, when it is broken by the iftar meal.

14 The period following the 1992-1995 war in Bosnia and Herzegovina saw attempts to advance the thesis that certain folk musical instruments in the country were to be identified exclusively with one or another ethnic group. Thus the saz was regarded as a Bosniac instrument, the šargija as an instrument of the Bosnian Croats, and the gusle as the Serb national instrument. Bosian ethnomusicologists have demonstrated on the basis of historical sources and recent research that this thesis is unsustainable. 
(Lajić Mihajlović 2014:141). Many guslars belonging to this category also record CDs released by private or local record companies. These are commercial recordings which are most often intended to meet the performer's need for promotional materials, and not a desire to preserve the traditional manner of telling a story through song.

\section{Storytelling through song}

Narratives expressed by the guslars through song had very diverse subjects - from heroic lays, epics, and traditional ballads to comic songs and songs about local communities and personal life. The differing profiles of gusle players influenced the creation of their personal repertoires. Nevertheless, pride of place is held by heroic epics which describe heroes from the period of the Ottoman Empire. Zlatan Čolaković believes that Bosnian epic is a traditional art comprising historical-mythical stories in verse, generally sung to the accompaniment of the gusle or tambura. The beginning of its development in the second half of the fifteenth century is contemporary with the advent of the Ottoman Empire. Certain forms of autonomous South Slav epics, narrative, lyrics and ballads existed in Bosnia and its wider neighbourhood ${ }^{15}$ (http://bosnjaci.net/prilog. php?pid=15278). The gusle was a very popular instrument, and memories of many figures and events from the distant past and recent history were preserved through its aid. Songs might have several hundred lines, and they represented the living historical memory of a particular social community. I shall mention here just a few of the figures who appear frequently in Bosnian epic songs.

One of the figures to appear most frequently in epic songs, especially those of Muslims, is Alija Đerzelez (Đerzelez means a warrior armed with a mace) ${ }^{16}$. According to the information available, Đerzelez was a warrior and hero who lived at the close of the fifteenth century. He is believed to have died in the village of Gerzovo near Mrkonjić Grad, where his mausoleum (turbe) is located. Đerzelez is first mentioned in one of a collection of bugarštice ${ }^{17}$ published by Baltazar Bogišić at the end of the nineteenth century (Bugarštica no. 13), but recorded by Đuro Matei at the turn of the eighteenth century (1878:40). Texts of songs about Alija Đerzelez are found in numerous collections from the late nineteenth century, and were recorded by Murko, Parry and Rihtman ${ }^{18}$.

The memory of the hajduk (social bandit) Mijat (Mihovil) Tomić (first half of the seventeenth century) from the village of Gornji Brišnik near Tomislavgrad ${ }^{19}$ has been

The material construction of the gusle often includes motifs with a symbolic meaning: a horse's head, a snake, a mounted hero, etc. According to Cvjetko Rihtman, these motives may be related to an earlier function of epic poetry (1971:97).

16 Alija Đerzelez appears in Albanian epics under the name Gjergj Elez Alia.

17 The bugarštica is a form of South Slavic epic and ballad poetry.

18 The Bosnian author and Nobel laureate Ivo Andrić wrote Put Alije Đerzeleza [The Path of Alija Đerzelez], published in 1920.

19 In response to the then current political situation in Bosnia and Herzegovina the Hajduk Republic of Mijat Tomić was founded in his memory on June 5, 2002. The republic lies in the area between the mountains of Vran and Čvrsnica, in the middle of the Nature Park Blidinje (western Herzegovina). The seat of this republic is the Hajducke vrleti motel, whose owner is the sole ruler of this micro-nation. The founding of political parties and political is prohibited in the Republic because it would distort the legal order and public health. Legal order is protected and cherished by an elite guard of soldiers. The republic has its own currency, constitution, flag, anthem and passports. (see http://www.hajduckevrleti-blidinje.com/index.php?page $=3$, accessed on 3.08.2014.) 
preserved through guslars' songs. Tomić and his band had a hideout on Mount Vran and fought successfully against Ottoman rule for many years. Jeronim Vladić recorded that the inhabitants of Rama often spent their nights listening to heroic songs and the gusle. These songs celebrated heroes and hajduks, including a "neighbour from Duvno [present-day Tomislavgrad], Tomić Mihovile from the heights of Mount Vran above the plain of Duvno”. (Vladić 1991:12) Songs about Mijat Tomić exist in numerous records (Krsto Marković, Matica hrvatska no. 141; Mihovil Pavlinović, Matica hrvatska no. 143; Luka Marjanović) and were recorded in collections from the first half of the twentieth century (Murko Collection, Phonogrammearchiv of the Austrian Academy of Sciences; Parry Collection, Widener Library of Harvard University; Rihtman Collection, Institute of Musicology of the Academy of Music in Sarajevo). During fieldwork in Rama and Prozor in 2008, I recorded two songs sung to the gusle by Ivan Sabljo - The Song of Mijat Tomić and The Song of Doljani. The first song tells of Tomićs heroic actions, while the second is about his death.

The brothers Mujo and Halil Hrnjica, Vuk Jajčanin, Bey Ljubović, Budalina Tale and many others were also mentioned in song. In Eastern Herzegovina many songs were sung about Serbian hero Marko Kraljević (Prince Marko). Songs about these heroes are often performed even today.

The guslar Milovan Vojičić (1901), an agricultural worker from Nevesinje, was one of Milman Parry's informants. His repertoire included epic songs about the battle of Kosovo, the assassination of Franz Ferdinand in 1914 in Sarajevo, and fighting against the Austro-Hungarian army, but also songs about such heroes as Mijat Tomić and Alija Đerzelez. Vojičić's repertoire included a number of traditional ballads in addition to these epic songs. The Milman Parry Collection includes a letter from Milovan Vojičić dated 1934, in which he writes that he has received a letter from Parry and money for the books. He also mentions that he is sending him another two song books and that he is still writing and trying to include good songs in the book. A considerable number of these written songs had been transmitted orally and there were several songs that Vojičić had composed himself. One of these is dedicated to Milman Parry.

A large number of gusle songs and interviews with guslars were recorded by Cvjetko Rihtman. It may be concluded from Rihtman's interview with the guslar Dušan Kovačević (Kifino village near Nevesinje, 1902) that although the greater part of his repertoire was dedicated to epic songs about heroes and events from the period of Ottoman Empire, he also treated important events from the history of Bosnia and Herzegovina. Kovačević states that the Sarajevo assassination was first mentioned in a song by Aleksa Guzina from the village of Fojnica near Gacko, and that many guslars subsequently included that song in their own repertoires. In 1928 a severe drought affected Eastern Herzegovina, inspiring Kovačević to create a sung narrative about the harsh life of the local population and other disastrous events caused by the drought.

Todor (1896) and Lazar (189?) Radak, two brothers from village Lobovo near Šipovo (central Bosnia), were extremely good makers and players of the gusle ${ }^{20}$ and were informants of Matija Murko and Cvjetko Rihtman. Their repertoire was large and diverse.

20 Lazar Radak was awarded the title of "Best guslar of Yugoslavia" in 1927. 
It consisted of well-known epic songs about warriors, the battle of Kosovo, but also contained songs which they had written themselves and in which important events from the life of Šipovo and other nearby villages were narrated.

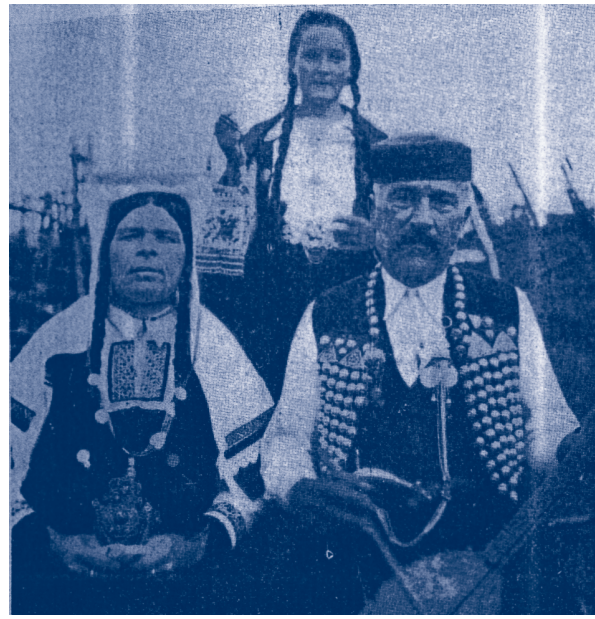

Figure 1: Guslar Lazar Radak and family (photo C. Rihtman, Lubovo, 1951)

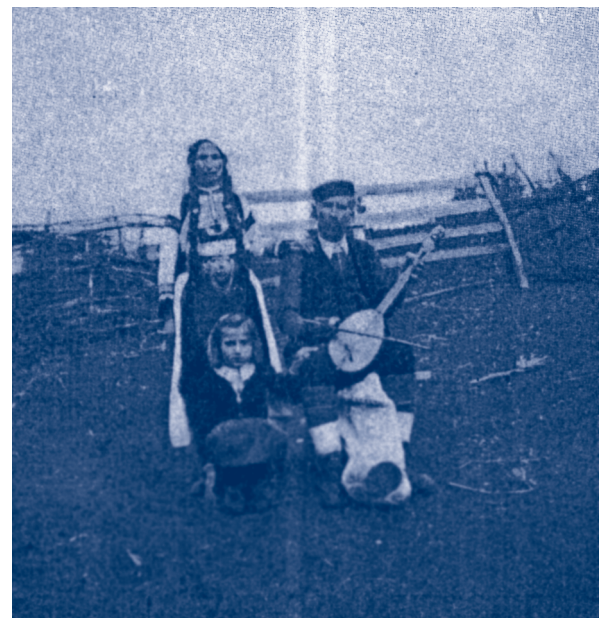

Figure 2: Guslar player Todor Radak (photo C. Rihtman, Lubovo, 1951)

Just before the end of the Second World War Lazar Radak sang The Liberation of Šipovo, which was recorded by Peter Kennedy in $1951^{21}$.

Oj, neka pravde, sloge i slobode, /O long live Justice, Harmony and Freedom, nek svi žive koji narod vode, / long life to all leaders of the people, o, svom narodu čuvaju slobode. / they guard over the freedom of all the people, Na hiljadu devete stotine, / In the year one thousand, nine hundred četrdeset $i$ prve godine, / and forty-one, procvilila sirotinja raja, / the poor enslaved people cried out, jadna raja iz svakoga kraja / those miserably enslaved from every region, od sve Bosne i Hercegovine.../ from all Bosnia and Herzegovina...

Šećo Kadrić (Umoljani, Mt Bjelašnica near Sarajevo, 1935) was taught to play the gusle by his father Dervo Kadić (1910-1964). He played for many years at family gatherings and house parties (Bosnian: sijelo) in Umoljani and nearby villages ${ }^{22}$.

21 Peter Kennedy (1922-2006) was an English collector of folk songs who was active in the 1950s. Peter Kennedy recorded at the International Folk Music Festival in Opatija (Croatia) in September 1951. Kennedy's recordings were issued in 2001 as part of the Alan Lomax Collection: World Library of Folk and Primitive Music: Yugoslavia (Volume 5, compiled and edited by Alan Lomax).

22 During my fieldwork in May 2011 in Umoljani village informants told me that although there were several gusle players in the village Šećo Kadrić was the best. I recorded his singing and playing gusle. Unfortunately, Šećo's hearing and age affected his interpretation. His singing and playing were not often coordinated. However, his good memory, ability to interpret the text and his skilful technique confirmed that he was an extremely good singer and gusle player. Šećo talked about many other details from his life. He confirmed that he received monetary awards for his performances. After the performance, listeners would place money on the top of his resonant body which was covered with leather. Today, Šećo Kadrić is only gusle player in Umoljani. 


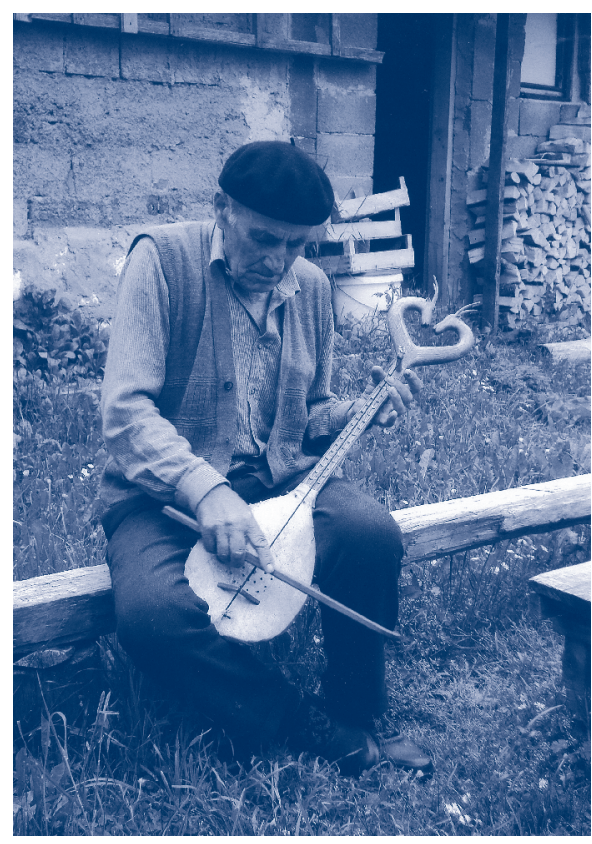

Figure 3: Guslar Šećo Kadrić (Umoljani, 1935), Umoljani 17. 05. 2011. Photo Petra Hamer.

His repertoire was varied, and most of the songs in his repertoire were learned from his father. One of Šećo's favourite songs is the traditional ballad Ženidba bega Ljubovića (The Wedding of Bey Ljubović) which he performs in his own style. Over the years he has also composed several songs himself. His favourite song speaks about his departure to the army in 1956. In that song, he describes the small mountain village of Umoljani, the life of the people who live there, and his family in particular. Most of the song is taken up with his departure from the village. Šećo described, in a very picturesque fashion, the challenges that a young person faces when leaving the village for the first time.

The narrative creativity of gusle players is expressed through various cheerful and witty songs. I recorded several such songs in various places in Bosnia and Herzegovina. A Trebinje guslar, Lazar Ambulija ${ }^{23}$, sang a very interesting comic song about women who have no job and like to gossip, while unlucky menfolk had to accept a life with such a woman.

Neko priču istinitu kaza, / Someone told the true story, istina je, moga mi obraza, / it is the truth, I swear za razvod se braka nije znalo, / divorce is an unknown thing nego čuvaj šta te je dopalo.../ keep whatever you got...

23 I recorded Lazar Ambulija in 2007 in Sarajevo at the launch of a calendar featuring images of traditional clothing from Bosnia and Herzegovina. 
I also recorded a song by guslar player Mile Ćališ ${ }^{24}$ (Podbor, 1962), Gusle moje od javora suva (My gusle of seasoned maple).

Gusle moje od javora suva, / My gusle of seasoned maple,

di vas nema tu je kuća gluva, / the house is deaf without your voice,

kad vas uzmem u junačke ruke, / I take you in my hero's hands

pola svoje zaboravim muke.../ And half my woes are soon forgotten...

Although it is a truism that guslars are generally male, there are also women in rural Herzegovina who sang and played the instrument. A few years ago I became acquainted with the guslarka (female guslar) Ruža (Galić) Jolić (Kongore, Tomislavgrad, 1945), who learned to play the gusle from her grandmother Ruža Baćak (1860-1958) and today plays her own instrument. Her repertoire is varied and consist of old epic poems, and new ones which she has composed herself.

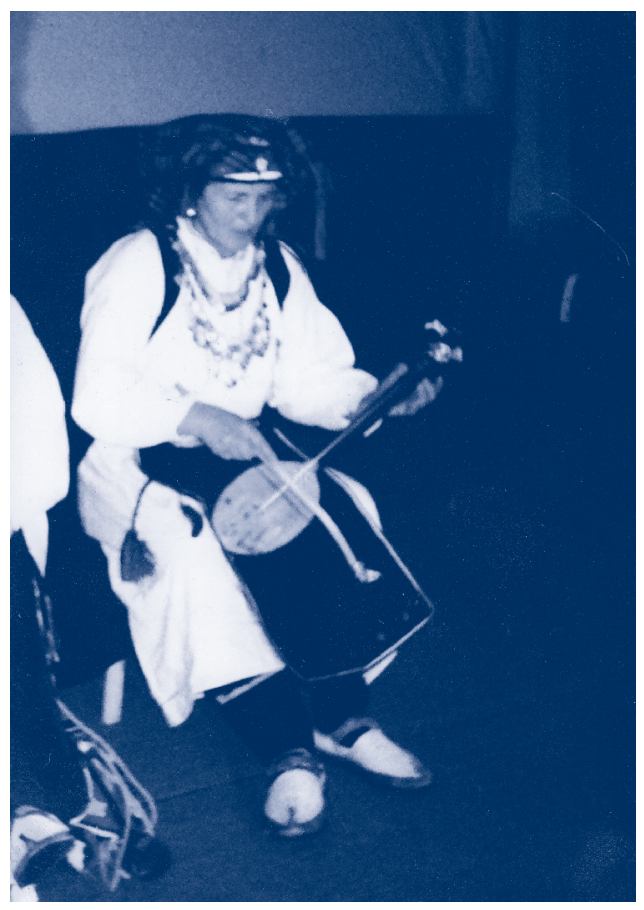

Figure 4: The guslarica (female guslar) Ruža Jolić (Kongore, Tomislavgrad, 1945), photo Miroslav Šilić.

Ruža lives in Duće near Omiš (Croatia), and has a solid reputation. She described her public performance in a press interview.

24 I recorded Mile Ćališ singing to gusle accompaniment during fieldwork in Rama and Prozor in 2008. 
"The performance takes about five minutes or so, though I could do longer, but the programme is often such that you have to keep it short. The other guests need to have a chance. And in them five minutes you're meant to tell them something about our heroic past, or some kind of a love story. I've got all manner of songs, for the youngsters, for the kiddies... Something for everyone. But I took good care to get proper prepared for them ones about the past, I read these old books about our hajduks and other heroes, from when it was Austria-Hungary right down to now." (Slobodna Dalmacija, 2010)

Ruža Jolić has published a book, Pisme za gusle (2009), containing 95 poems on various subjects.

\section{In place of a conclusion}

Narrative poetry played a very significant role in the folk music tradition of Bosnia and Herzegovina, and still does today. The subjects of the poems are various, ranging from heroic epics to poems describing the detail of everyday life. The function of epic poetry is primarily educational, and is aimed "at fostering in young people the heroism and values that are sung of" (Rihtman 1971:97). Guslars were highly inventive, frequently adding new lines to existing songs and creating new ones that adhered to established traditional forms. Lord concluded that "every performance is unique, and every performance bears the signature of its poet singer" (2000:4). Singing to gusle accompaniment was handed down from generation to generation by oral transmission, and from the nineteenth century onwards by printed songbooks. A considerable number of guslars' songs are still performed today. New songs also appear which describe events from the recent history of Bosnia and Herzegovina. It may thus be concluded that throughout all historical periods a new selection was made from the poetic and musical expressions of the past, and this became the tradition in its turn.

\section{Bibliography}

Bogišić, Baltazar. Narodne pjesme iz starijih, najviše primorskih zapisa. Biograd,1878. Čubelić, Tvrtko. "Uvodne napomene". In Rad 15. kongresa SUFJ. Cvjetko Rihtman, ed. Sarajevo: Udruženje folklorista BiH, 1971, 161-196.

Dukić, Davor. "Razotkrivanje epskoga života - Murkov pristup južnoslavenskoj narodnoj epici”. In Zbornik prispevkov s kongresa Razvoj slovenske etnologije od Štreklja in Murka do do sodobnih etnoloških prizadevelj. Rajko Muršič and Mojca Ramšak, eds. Ljubljana: Slovensko etnološko društvo, 1995, 51-57.

Foley, John Miles. The Wedding of Mustajbey's Son Bećirbey as performed by Halil Bajgorić. Helsinki: Suomalainen Tiedeakatemia, 2004.

Krauss, Friedrich Salomo. Pjesan naših Muhamedovaca. Dubrovnik: Knjižarnica D. Pretnera, 1886. 
Kuhač, Franjo. 1877. "Prilog za povjest glasbe južnoslovjenske". U Rad JAZU. Knjiga XXXVIII. Zagreb: JAZU, 1877, 1-77.

Kunić, Mirsad. "Antoine Meillet - Saussureov učenik, a Parryjev učitelj”. Lingvazin. I/3. (Tuzla: Institut za bosanski jezik i književnost, 2013): 23-25.

Kuripešić, Benedikt. Putopis, kroz Bosnu, Srbiju, Bugarsku i Rumeliju. Beograd. Cigoja štampa, 2001.

Lajić Mihajlović, Danka. Srpsko tradicionalno pevanje uz gusle: guslarska praksa kao komunikacijski proces. Beograd: Muzikološki institut SANU, 2014.

Lord, Albert B. The Singer of Tales. Cambridge, Mass: Harvard University Press, 2000.

Marić, Branko. "Naša pučka glazbala”. Sarajevo: Napredak, 1932, 139-148.

Murko, Matija. Tragom srpsko-hrvatske narodne epike. Putovanja u godinama 19301932. Zagreb: JAZU, 1951.

Murko, Matija. 1974. "Epska narodna poezija u Jugoslaviji početkom XX vijeka". In Narodna književnost Srba, Hrvata, Muslimana $i$ Crnogoraca. izbor studija $i$ članaka. Đenana Buturović and Vlajko Palavestra, eds. Sarajevo: Svjetlost, 1974, 163-164.

Murko, Vladimir. "Građa sudbina literarne ostavštine i fonografskih snimaka srpskohrvatskih epskih pjesama Matije Murka”. Narodna umjetnost. Vol. 2, No. 1. (1964): $107-137$.

Renner, Henrik. Herceg-Bosnom uzduž i poprijeko. Preveo: Isa Velikanović. Sremska Mitrovica: Hrvatska dionička tiskara (N. Dogan), 1900.

Rihtman, Cvjetko. "Tradicionalni oblici pjevanja epskih pjesama u Bosni i Hercegovini”. In Rad 15. kongresa Saveza udruženja folklorista Jugoslavije, Cvjetko Rihtman, ur. (Sarajevo: Udruženje folklorista Bosne i Hercegovine, 1971), 97-105.

Rihtman, Cvjetko. "O stvaraocima i prenosiocima u oblasti narodne muzičke tradicije". In Rad 27. kongresa Saveza udruženja folklorista Jugoslavije, Cvjetko Rihtman, ur. (Banja Vrućica. Udruženje folklorista Bosne i Hercegovine, 1982), 240-246.

Rihtman, Cvjetko. 1998. "Napjev balade u narodnoj traqdiciji Bosne i Hercegovine". Muzika. 3/7(1998): 6-8.

Talam, Jasmina. Folk musical instruments in Bosnia and Herzegovina. Newcastle: Cambridge Scholars Publishing, 2013.

Vladić, Jeronim. Uspomene o Rami i ramskom franjevačkom samostanu. Prozor: Matica hrvatska, 1991.

Accessed August 3, 2014.http://www.hajduckevrleti-blidinje.com/index.php?page=3.

Julardžija, Enver i Krcić, Esad. "Bošnjačka epika je jači svjedok od pisane historije" (intervju sa prof. dr. Zlatanom Čolakovićem). January 5, 2003. Accessed July 29, 2014. http://bosnjaci.net/prilog.php?pid=15278.

Šimundić Bendić, Tanja. Ruža Jolić iz Duća - jedina hrvatska guslarica. Accessed May 9, 2010. Slobodna Dalmacija. http://www.slobodnadalmacija.hr/Novosti/Hrvatska/ tabid/66/articleType/Article Accessed July 29, 2014. View/articleId/101824/Rua-Joli-iz-Dua-jedina-hrvatska-guslarica.aspx. 


\section{POVZETEK}

Péto nastopanje s spremljavo gusel je ena najpomembnejših in najpogostejših oblik ljudske glasbene produkcije $v$ Bosni in Hercegovini. Guslarji prihajajo iz vseh družbenih slojev, njihova starost, izobrazba in interesi pa precej nihajo. Še posebej znani so bili nadarjeni guslarji/pevci, katerih interpretacije temeljijo na znanju, ki so ga pridobili z ustnim izročilom in skozi dolgoletno prakso. Pesmi guslarjev so se prav tako razlikovale po svoji tematiki: epska poezija, ljudske balade in poročila o pomembnih dogodkih. Pevci so improvizirali ali priredili obstoječe pesmi v večji ali manjši meri tako, da so dodajali vrstice ali pa ustvarili nove pesmi, $v$ katerih so opisovali aktualne dogodke. Tradicija petja ob spremljavi gusel se je prenašala iz generacije $\mathrm{v}$ generacijo z ustnim izročilom, od 19. stoletja naprej pa s pomočjo natisnjenih knjig. Dosedanje raziskave poročajo, da se je način, kako nastajajo pesmi za gusle, kako se jih je prenašalo in izvajalo, $s$ časom spremenil, razloge za to pa lahko pogosto najdemo v načinu petja ob spremljavi gusel. Petje ob spremljavi gusel se je tradicionalno izvajalo ob različnih priložnostih, predstavljalo pa je najpomembnejše razvedrilo na podeželju. V zadnjem času se je tradicionalna funkcija petja ob guslah umaknila iz ljudske glasbe; kljub temu ostaja petje ob guslah precej priljubljeno tudi dandanes. Guslarji so še zmeraj izjemno domiselni, skladajo nove pesmi, navdahnjene $\mathrm{z}$ dogodki bosanske zgodovine in prirejajo obstoječe pesmi v skladu $\mathrm{z}$ individualnim slogom. 